\title{
Determining the Effect of Hesperidin Supplementation to Japanese Quail Rations on Blood Serum, Tissue Antioxidant Parameters, Intestine Histomorphology, and Feces Microflora
}

Abdullah ÖZBILGIN

Cumhuriyet Üniversitesi: Sivas Cumhuriyet Universitesi

Mahmut MOGULKOÇ

Cumhuriyet University: Sivas Cumhuriyet Universitesi

Füsun ERHAN

Cumhuriyet University: Sivas Cumhuriyet Universitesi

Nazlı ERCAN

Cumhuriyet University: Sivas Cumhuriyet Universitesi

Kanber KARA ( $\square$ karakanber@hotmail.com )

Erciyes University https://orcid.org/0000-0001-9867-1344

\section{Research Article}

Keywords: Blood, feces, flavonoid, tissue

Posted Date: October 28th, 2021

DOI: https://doi.org/10.21203/rs.3.rs-984924/v1

License: (c) (1) This work is licensed under a Creative Commons Attribution 4.0 International License.

Read Full License 


\section{Abstract}

This study was conducted to determine the effects of hesperidin, a flavonoid added to quail rations, on blood serum, antioxidant enzymes in tissues, intestinal histomorphology and fecal microflora. In this context, three groups have been created. The first group has been administered basal ration (Group C). The second group (HES1) has been administered basal ration with hesperidin ( $1 \mathrm{~g} / \mathrm{kg}$ feed). The third group (HES2) has been administered basal ration with additional hesperidin ( $2 \mathrm{~g} / \mathrm{kg}$ feed). The experiment lasted 35 days. Blood, tissue and feces samples were taken at the end of the experiment. A significant difference has been found in the blood serum in terms of ALT, AST, LDH and Amylase enzymes in the groups with hesperidin compared to the control group $(p<0.05)$. A significant difference was found in the hesperidine groups in tissue antioxidant GSH, CAT and SOD enzyme parameters compared to the control group $(p<0.05)$. When looking at the intestinal histomorphology, a significant difference has been found within the test groups in the colon in terms of both villus height and crypt depth, and at villus height in the cecum tissue. As a result, the study's hypothesis has been supported by the fact that hesperidin positively affects the lipid concentration of quail, rump, liver and serum antioxidant enzyme levels, intestinal histomorphology and feces microflora of anaerobe bacteria, particularly Clostridium spp.

\section{Introduction}

Molecules in living cells that prevent or delay the oxidation of structures such as proteins, lipids, carbohydrates are called antioxidants. Flavonoids are a group of plant-derived heterocyclic organic compounds divided into 14 different subgroups according to the chemical structure and positions of the components on rings A, B and C (Cushnie and Lamb 2011). Hesperidin is one of the primary flavonoids found in citrus fruit (Cano et al., 2008). Flavonoids are dietary supplements that are very well known for their antioxidant activity due to the presence of aromatic hydroxyl groups. Hesperidin (5, 7, 3'-trihydroxy4'-methoxy-flavanone 7-rhamno glucoside), a bioflavonoid, was formed from hesperidin and rutinose (Cho, 2006, Kumar et al., 2014).

Flavonoids have many biological properties, including antimicrobial, antioxidant and vascular activities (Martini et al., 2004). Studies report that flavonoids prevent free radicals and oxidative stress (Croft, 1998, Ross and Kasum, 2002). Other studies are saying that it promotes the activity of cellular antioxidant enzymes such as Superoxide Dismutase (SOD), Hemeoxygenase-1 (HO-1) and catalase (CAT) (Khedr, 2015, Roohbakhsh et al., 2015, Parhiz et al., 2015).

Flavonoids can be conjugated with glucuronic acid, and 0-methylation or sulfate ester formation may occur to facilitate consumability. This type of biotransformation occurs in the lower parts of the gastrointestinal tract. Some of the flavonoids that are not absorbed in the small intestine and other compounds are secreted by bile. They also contribute to the degradation process in the colon, in which microorganisms disrupt the ring structures (Hollman and Katan, 1999). In general, data on the intestinal absorption of hesperidin are insufficient, and its fate in the intestine is still unclear (Guo et al., 2020). 
This study has been conducted to determine the validity of the hypothesis that questions whether the addition of hesperidin to feed has positive effects on blood serum, antioxidants in some tissues, intestinal histology and feces microflora in quails. The results obtained will help understand the effects of the addition of hesperidine to the ration on blood serum, antioxidant concentration in tissues, intestinal histomorphology and feces microflora.

\section{Materials - Method}

\section{Chemicals}

Hesperidin (molecular formula: $\mathrm{C} 28 \mathrm{H} 34015$, cas no: $520-26-13$, purity $91 \%$, Chem-Impex International Company, USA) was extracted from orange fruit and was available from the market in powder form.

\section{Animals and dietary treatments}

This study has been initiated with the Ethics Committee Approval numbered 253/2019 by the Committee for the Purpose of Control and Supervision of Experiments on Animals (HADYEK).

Japanese quails (300 quails, weighing 40-45 g and 1-2 weeks old) were obtained from breeders in Sivas $\left(39^{\circ} 42^{\prime} 34.8^{\prime \prime} \mathrm{N} 37^{\circ} 01^{\prime} 13.0^{\prime \prime} \mathrm{E}\right)$. The animals were kept in metal cages of Çimuka brand (height: width: depth) $(20 \mathrm{~cm} * 45 \mathrm{~cm} * 90 \mathrm{~cm})$ with light for 21 hours and darkness for three hours at room temperature $\left(25 \pm 2^{\circ} \mathrm{C}\right)$.

The rations used in the experiment were formulated according to the recommendations of NRC (1994) and their chemical analysis was performed according to AOAC (2000) (Table 1). The quails were given ad libitum pellet feed and water. Before starting the experiment, an orientation period for the environment and the feed was applied for one week. The dose of hesperidin was determined as reported in previous studies (Goliomytis et al., 2015). It was divided into three groups as control and trial groups to study parameters such as blood serum, antioxidant, intestinal histology, and fecal microflora. It was distributed into five subgroups within these groups.

Control: $0 \mathrm{~g} / \mathrm{kg}$ of hesperidin was added to the basal ration.

HES1: $1 \mathrm{~g} / \mathrm{kg}$ of hesperidin was added to the basal ration.

HES2: $2 \mathrm{~g} / \mathrm{kg}$ of hesperidin was added to the basal ration.

\section{The blood, tissues and intestinal contents}

At the end of the feeding period, the animals, were weighed and slaughtered. Individual samples were taken from eight animals in each group. Samples of blood serum, liver, rump tissue, and ileum, cecum, and colon tissues, and intestinal contents from the cecum were obtained for various biochemical, serological, and histological examinations. 


\section{Blood serum analysis}

Blood sera were taken from the jugular vein into coagulant yellow-cap serum separator blood tubes (BD Vacutainer). After the blood was kept for 24 hours and centrifuged for 10 minutes at 3000 RPM, the serum collected at the top was transferred to $2 \mathrm{ml}$ Eppendorf tubes. The sera were frozen in a freezer at $-80^{\circ} \mathrm{C}$ until the analysis was performed and then stored. Biochemical values were determined in blood serum samples using an auto-analyzer device (Mindray BS200).

\section{Tissue Antioxidant Analysis}

At the end of the experiment, the following analyses were conducted on blood serum, liver and rump tissue taken from quails.

\section{Reduced Glutathione (GSH)}

$0.1 \mathrm{~g}$ of liver and muscle samples were weighed, and $0.9 \mathrm{~mL}$ of physiological saline solution (SF) was added. The tissue homogenizer was homogenized for 30 seconds. Then, it was centrifuged for 10 minutes $\left(+4^{\circ} \mathrm{C}\right)$ at $2500 \mathrm{rpm}$. After centrifugation, the supernatant part was removed, and $0.1 \mathrm{ml}$ of reagent 1 was added. It was centrifuged for 10 minutes at $4500 \mathrm{~g}$, and the supernatant portion was extracted. GSH levels in tissue and serum samples were determined using the ELABSCIENCE (E-BC-K030M) commercial kit on a microplate reader (Thermo Multiscan) following kit procedures. In calculating the absorbance values, a calibration curve was created and the GSH levels corresponding to the absorbances of the samples were calculated as $\mu \mathrm{mol} / \mathrm{L}$.

\section{SOD}

The $0.1 \mathrm{~g}$ of liver and muscle samples were weighed. $0.9 \mathrm{~mL}$ of PBS was added. The tissue homogenizer was homogenized for 30 seconds. Then, it was centrifuged for 10 minutes $\left(+4^{\circ} \mathrm{C}\right)$ at $10000 \mathrm{~g}$. After centrifugation, the supernatant part was removed. SOD levels in tissue and serum samples were determined using the ELABSCIENCE (E-BC-K022-M) commercial kit on a microplate reader (Thermo Multiscan) in accordance with kit procedures. SOD levels were calculated as $\mathrm{U} / \mathrm{L}$ in response to the absorbances of the samples.

\section{Catalase (CAT)}

The $0.1 \mathrm{~g}$ of liver and muscle samples were weighed, and $0.9 \mathrm{~mL}$ of physiological saline (PBS) $(0.01 \mathrm{M}$ $\mathrm{pH}$ 7.4) was added. The tissue homogenizer was homogenized for 30 seconds. Then, it was centrifuged for 10 minutes $\left(+4^{\circ} \mathrm{C}\right)$ at $1500 \mathrm{~g}$. After centrifugation, the supernatant part was removed. CATALASE levels in tissue and serum samples were determined using the ELABSCIENCE (E-BC-K031-M) commercial kit on a microplate reader (Thermo Multiscan) following kit procedures. In the calculation of the absorbance values, a calibration curve was created and the catalase levels corresponding to the absorbances of the samples were calculated as $\mathrm{U} / \mathrm{ml}$. 


\section{TBARS}

The $0.1 \mathrm{~g}$ of liver and muscle samples were weighed, and $0.9 \mathrm{~mL}$ of SF was added. The tissue homogenizer was homogenized for 30 seconds. Then, it was centrifuged for 10 minutes $\left(+4^{\circ} \mathrm{C}\right)$ at 10000 g. After centrifugation, the supernatant part was removed. TBARS levels in tissue and serum samples were determined using the ELABSCIENCE (E-BC-K298-M) commercial kit on a microplate reader (Thermo Multiscan) following kit procedures. In calculating the absorbance values, a calibration curve was created and the TBARS levels corresponding to the absorbances of the samples were calculated as $\mu \mathrm{mol} / \mathrm{L}$.

\section{Lipid Peroxide (LPO)}

The $0.1 \mathrm{~g}$ of liver and muscle samples were weighed, and $0.9 \mathrm{~mL}$ of PBS $(0.01 \mathrm{M} \mathrm{pH} 7.4)$ was added. The tissue homogenizer was homogenized for 30 seconds. Then, it was centrifuged for 10 minutes $\left(+4^{\circ} \mathrm{C}\right)$ at $10000 \mathrm{~g}$. After centrifugation, the supernatant part was removed. LPO levels in tissue and serum samples were determined using the ELABSCIENCE (E-BC-K176-M) commercial kit on a microplate reader (Thermo Multiscan) following kit procedures. In calculating the absorbance values, a calibration curve was created and the LPO levels corresponding to the absorbances of the samples were calculated as $\mu \mathrm{mol} / \mathrm{L}$.

\section{Intestinal Histomorphology}

At the end of the experiment, eight animals from each group were sampled after the quails were slaughtered. lleum, cecum and colon samples were detected in tissue containers for histological preparation in a $10 \%$ buffered formula and washed in tap water for 48 hours. $5 \mu \mathrm{m}$ thick sections were taken after the tissues, followed by the histological tissue follow-up method that was applied routinely, were blocked in the parablast. Hematoxylin - Eosin staining was performed sectionsto determine the sections' overall histological structure and perform histometric measurements (Bancroft, 2002). The stained preparations were examined under a research microscope (Zeiss Primo Star model) and their photos were taken. Villus height, villus width and crypt depth of the 10 pieces obtained from different parts of three sections belonging to each animal were measured using the ImageJ software. The villus height was measured at the vertical distance from the villus peaks to the starting point of the crypts, while the villus widths were obtained from measurements taken at the medium height of the villus. The depth of the crypt was calculated as the vertical distance from the villus-crypt junction to the lower boundary of the crypt (Kamboh and Zhu, 2014).

\section{Enumeration of intestinal microflora}

On day 35 , eighteen quails from each main group (three pens of six broilers per treatment) were slaughtered, and their intestinal tracts were immediately removed.

For the isolation and enumeration of intestinal microflora, one gram of caecal content from each quails was aseptically collected and homogenized with $9 \mathrm{~mL}$ of $0.1 \%$ peptone water. Serial 10 -fold dilutions were made in sterile peptone water from $10-1$ to $10-6$ and $0.1 \mathrm{ml}$ from last three dilutions were plated in duplicate onto respective selective medias. 
Escherichia coli counts were performed on Tryptone Bile X-Glucuronide (TBX) agar and incubated for 24 hours at $37^{\circ} \mathrm{C}$. Enterococci were cultured on Slanetz Bartley agar (SB, Oxoid CM377) and enumerated after $24-48$ hours of incubation at $37^{\circ} \mathrm{C}$. Enterobacteriaceae and coliforms were grown on Violet Red Bile Glucose agar (VRBG, Oxoid CM485) and Violet Red Bile agar (VRB, Oxoid CM107) respectively, using the pour plate technique and enumerated after $24-48$ hours of incubation at $37^{\circ} \mathrm{C}$.

Tryptose Sulfite Cycloserine Agar (TSC Agar) Base (Merck 1.11972) was utilized for the Clostridium count. The plates were incubated for $24 \mathrm{~h}$ at $45^{\circ} \mathrm{C}$ under anaerobic conditions, anaerobic indicator (Mitsubishi) was included to monitor the atmospheric condition.

Petri dishes observed 30 to 300 colonies were counted using a colony counter (Jin et al., 1996).)

The microbial counts were expressed as log10 cfu per gram of caecal contents.

\section{Statistical Analysis}

The data obtained were evaluated using the SPSS 20.0 statistical package software. One-way analysis of variance (ANOVA) was used to determine whether there was a statistical difference between the data in all parameters. İ contrast, the Bonferroni multiple comparison test was used in binary comparisons between the groups $(P<0.05)$.

\section{Findings}

A significant difference in ALT, AST, LDH and Amylase enzyme parameters was detected in the blood serum between the trial groups $(p<0.05)$ (Table 1). However, no significant differences were found between the trial groups in the parameters of Tchol, TG, GGT, ALP, CK, BUN, Albumin, TP, Urea, Creatine, Glucose, $\mathrm{Ca}, \mathrm{Mg}$ and Phosphorus ( $p>0.05)$.

In terms of the SOD parameters among rump, liver and serum samples within experiment groups in terms of GSH, LPO, CAT and TBARS parameters as an antioxidant in specific tissues, only the rump samples showed a statistically significant difference among the experiment groups $(P<0.05)$ (Table 2$)$. However, there was no significant difference between the experimental groups in the liver and serum samples in the SOD parameter $(p>0.05)$

In terms of histomorphology in the intestine, no significant differences were detected in the measurements of villus height, villus width and crypt depth in ileum tissues $(p>0.05)$ (Table 3$)$. A significant increase in the height of the cecum villus was observed $(p<0.05)$, while there was no significant increase in the width of the villus and the depth of the crypt $(p>0.05)$. In colon tissues, the increase in villus height and width and the decrease in crypt depth were found to be significant $(p<0.05)$ (Figure 1).

A significant difference was found between the experiment groups in terms of the Clostridium spp parameter in the samples of microflora in the content of fresh feces $(p<0.05)($ Table 4$)$. However, there is 
no significant difference between the experiment groups in terms of Escherichia coli, Enterococcus spp., Coliform spp. and Enterobactericeae parameters $(p>0.05)$.

\section{Discussion}

\section{Serum biochemistry}

Dietary antioxidant supplements can improve the physiology and yield characteristics of animals by changing metabolic processes. The current study aimed to investigate the effects of hesperidin on biochemical parameters and antioxidant indices in quails. Citrus flavonoids, such as hesperidin and naringin, obtained from citrus fruits and fruit juices have been associated with lower cholesterol and triglyceride levels in animals in the previous studies (Selvaraj and Bugalendi, 2012, Ohtsuki et al. 2003). The hypocholesterolemic effect of hesperidin has been reported to be mediated by a decrease in the activity of HMG-Co A reductase (Lee et al., 1999). In the current study, it was found that both triglyceride and cholesterol levels decreased in the groups with hesperidin.

Antioxidant compounds taken from the diet, such as bioflavonoids, can protect some protection against the early stage of diabetes and the development of complications. It has been reported that hesperidin significantly reduces glucose in the blood (Jung et al. 2004). However, unlike previous studies, the serum glucose concentration increased slightly in the current study. To interpret the increase in glucose concentration, it is necessary to look at the plasma insulin concentration.

\section{Antioxidant Enzymes}

Under physiological conditions, reactive oxygen species (ROS) production is regulated both endogenously and by antioxidant supplementation (Birben et al., 2012, Liu et al., 2018). The main endogenous antioxidant enzymes are superoxide dismutase (SOD), catalase (CAT) and glutathione peroxidase (GPX) (Pingitore et al. 2015). SOD converts hydrogen peroxide, which is one of the superoxide radicals, into oxygen and water under the action of CAT and/or GPX. While SOD and GPX are formed in many tissues (Griess et al., 2017), CAT is highly present in liver, kidney and red blood cells (Glorieux and Calderon, 2017). The membranes of immune cells are made of highly polyunsaturated fatty acids, making them highly sensitive to oxidative stress (Knight, 2000). Therefore, they present high concentrations of antioxidant enzymes since membrane-related signaling and gene expression are critical for maintaining immune cell functionality (Estruel-Amades et al., 2019). In the current study, it is believed that the concentrations of rump and serum tissues and liver and serum tissues in terms of GSH parameter and CAT parameter, respectively, increase in relation to the hesperidin supplementation. In another study, it has been reported that the concentration of hesperidin in animals was lower in terms of SOD activity in rats undergoing a fatigue test (Estruel-Amades et al., 2019). Lien et al. (2008) and Ting et al. (2011) reported that the concentration of superoxide dismutase (SOD) in the blood serum was high with the addition of hesperidin and naringin $(0.5-4 \mathrm{~g} / \mathrm{kg})$ to broiler rations. Similarly, in the current study, the concentration of SOD enzymes in rump samples was found to be low, but as high as expected in liver 
tissue. In general, this effect of hesperidin on the oxidation parameter shows that it can terminate oxidation by adding hydrogen atoms to free radicals.

They reported that a significant decrease in MDA concentration had been observed in broilers consuming rations with grape pulp $(1.5,3$ and $6 \%)$ in terms of TBARS, which is one of the oxidant parameters, compared to those consuming a basal diet (Brenes et al., 2008, Goni et al., 2007). In another study, when broilers were fed a commercial essential oil mixture ( $0.05 \%$ of the diet), a decrease in MDA was observed in the breast (22.4\%) and rump 62.3\%) muscles (raw and warm tissue) when fed with a commercial essential oil mixture (Botsoglou et al., 2004). In addition, the addition of hesperidin $(0.15 \%$ or $0.3 \%)$ to the rations of broilers has been reported to reduce the concentration of MDA in the breast muscle (Simitzis et al., 2011). In the current study, as in the studies noted above, it is denser in the liver due to hesperidin, and the MDA value decreased in the same way in rump and serum. In addition, a decrease in LPO, which is an essential parameter in terms of tissue damage, is expected from the point of view of the current study due to the dose of hesperidin in rump and liver tissue. It is believed that this is because that the body fat composition of adult quails is rich in unsaturated fatty acids.

\section{Intestinal Histomorphology}

Hesperidin sulfates will be conjugated and absorbed in the duodenum and ileum after oral administration. Previous studies have shown a small amount of absorption of flavonoid glycosides in the small intestine (Escudero-Lopez et al., 2014). The absence of glucuronide detection in intestinal tissue may be due to the restriction of tissue penetration of glucuronide (Joshi et al., 2018).

Recent studies have reported that flavonoids in a natural form (flavonoid-rich plants) or the extracts thereof had positive effects on immunomodulatory and intestine, including the increasing villus length in broilers and surface area of the small intestine (Hanieh et al., 2010, Hassanpour et al., 2010, Wallace et al., 2010). Kamboh and Zhu (2014) found that, among broilers consuming added rations of hesperidin, the length of the intestinal villus and the width of the villus (21st and 42nd days) increased, while the depth of the crypt ( 21 days in the duodenum and ileum, and 42 days in the duodenum) decreased. In the current study, the height and width of the villus in the ileum, cecum and colon also increased relatively. Flavonoid compounds that improve intestinal morphology differences measured in villus height and width have shown that these compounds can stimulate epithelial cell mitosis. That is because longer or thicker (or both) villi are associated with active mitosis, and it is believed that the villi continue long-term absorption without the need for regeneration and a reduced crypt depth. This is because the crypt is considered a villus factory, and that the large crypt presents rapid tissue transformation due to inflammation caused by pathogens, toxins, or both (Giannenas et al., 2010, Awad et al., 2011). In addition, increased villus length/crypt depth ratios with genistein and hesperidin can be considered an improvement in the digestive system (Hu and Guo, 2007). It is expected that similar results to previous studies will be obtained in the current study.

\section{Feces Microflora}


Today, plant extracts commercially used in livestock due to their performance-enhancing and antimicrobial effects are available in pure or mixed form. It is known that phenolic compounds and essential oils obtained from plants have antimicrobial effects (Cross et al., 2007). The intestinal flora contained in the colon promotes the absorption of certain nutrients, including polyphenols, from the diet and forms bioactive and absorbable molecules from dietary compounds (Danneskiold-Sams $\varnothing$ e et al., 2019). Metabolites, consisting of both polyphenols and flora, can act on metabolic pathways and positively affect on health (Anhê et al., 2019). Additionally, numerous benefits of polyphenol metabolites derived by microflora on the host (Chávez-Carbajal et al., 2019) have been reported.

Flavonoids have the property of low bioavailability and poor absorption. Therefore, they significantly affect intestinal health (Etxeberria et al., 2013, Brenes et al., 2016). Phenolic compounds possess bactericidal (Gordon and Wareham, 2010) and bacteriostatic (Etxeberria et al., 2013) properties. They minimize the adhesion of pathogenic bacteria (E. coli, Clostridium spp.) to the intestinal wall and prevent infections in the digestive tract. They also improve the use of nutrients and animals' performance. (Viveros et al., 2011, Dueñas et al., 2015, Brenes et al., 2016).

Zhang et al. (2014) have reported in their study that polyphenols added in piglet rations did not have a significant effect on performance or feces E. coli and Clostridia spp. numbers on the 11 th and 21 st days. Kırkpınar et al. (2011) have noted a decrease in Clostridium spp. populations in the ileums of broilers fed with thyme oil, garlic oil and both substances compared to animals in other groups. Supplementation of cranberry extract ( $80 \mathrm{mg} / \mathrm{kg}$ feed), which is a source of phenolic acid, anthocyanin, flavonol and flavan-3ol, to broiler rations has decreased Enterococcus spp. signicantly populations in broilers on the 28th of the study (Leusink et al., 2010). In the current study, a lower concentration was determined in hesperidin groups in terms of the population of Clostridium perfiringens in a similar way to the previous studies.

\section{Results}

Hesperidin added to quail rations had the expected lowering effect on the concentration of TG and Tchol among biochemical parameters. The effect of ALT, a liver enzyme, on AST is lowering. It is believed that the dose-dependent variable effect on LDH and Amylase enzymes is related to the dose of hesperidin. Dietary supplement hesperidin has a positive effect on antioxidant enzymes GSH, CAT and SOD. In addition, it had a lowering effect on TBARS and LPO concentrations as expected. It was found that hesperidin supplementation increases the absorption surface in villi and crypts in the ileum, absoption site. In addition, it has been found that it increases the height of the villi in the cecum, the height of the villi and the depth of the crypt in the colon. Additionally, it has been observed that hesperidin supplementation decreased the concentration of E.coli, Coliform spp., Enterobactericeae in fresh feces taken at the end of the study, and significantly decreased Clostridium spp. bacteria in particular.

\section{Declarations}

\section{Acknowledgements}


The authors thank the financial support of the Scientific Research Project Fund of Sivas Cumhuriyet University, Sivas Province, Turkey.

\section{Author contribution}

All the authors worked in a coordinated way. The experiment was planned and conducted by A.Ö. under the guidance of K.K., which conducted to preparation-writing of manuscript, and F.E., which carried out histo-morphological analyses, and M.M. which analysed fecal microflora, and N.E., which carried out blood serum-tissue antioxidant analyses. All the authors read and approved the manuscript.

\section{Funding}

The study was supported with the grant project (the project number: V-094) by Scientific Research Project Fund of Sivas Cumhuriyet University, Sivas Province-Turkey.

\section{Data availability}

Data is produced from aforementioned Project.

\section{Code availability}

Not applicable.

\section{Ethics approval}

This study has been carried out with approve of Sivas Cumhuriyet University (39 $\left.42^{\prime} 34.8^{\prime \prime} \mathrm{N} 37^{\circ} 01^{\prime} 13.0^{\prime \prime} \mathrm{E}\right)$, Animal Experiments Local Ethics Board (Approved number: 253/2019).

\section{Consent to participate}

All the authors were aware regarding participation and publications.

\section{Consent for publication}

All the authors were aware regarding participation and publications.

\section{Conflict of interest}

The authors declare no competing interests.

\section{References}

1. Anhê, F.F., Nachbar, R.T., Varin, T.V., Trottier, J., Dudonné, S., Le Barz, M., Feutry, P., Pilon, G., Barbier, O., Desjardins, Y., Roy, D., Marette, A., 2019. Treatment with camu camu (Myrciaria dubia) prevents 
obesity by altering the gut microbiota and increasing energy expenditure in diet-induced obese mice. Gut, 68, 453-464. http://dx.doi.org/10.1136/gutjnl-2017-315565

2. AOAC, 2000. Official methods of analysis of AOAC International. 17th edn AOAC Int Maryland

3. Awad W.A., Ghareeb K., Bohm J., 2011. Evaluation of the chicory inulin efficacy on ameliorating the intestinal morphology and modulating the intestinal electrophysiological properties in broiler chickens. J. Anim. Physiol. Anim. Nutr. (Berl.), 95: 65-72. http://dx.doi.org/10.1111/j.14390396.2010.00999.x

4. Brenes A., Viveros A., Chamorro S., Arija I., 2016. Use of polyphenol-rich grape by-products in monogastric nutrition. A review. Anim. Feed. Sci. Tech., 211: 1-17. http://dx.doi.org/10.1016/j.anifeedsci.2015.09.016

5. Bancroft, J.D., Gamble, M., 2002. Theory and Practice of Histological Techniques. 5nd Ed. 125-231

6. Birben, E., Sahiner, U.M., Sackesen, C., Erzurum, S., Kalayci, O., 2012. Oxidative stress and antioxidant defense. World Allergy Organ. J. 5: 9-19. http://dx.doi.org/10.1097/WOX.0b013e3182439613

7. Botsoglou, N.A., Christaki, E., Florou-Paneri, P., Giannenas, I., Papageorgiou, G., Spais, A.B.,2004. The effect of a mixture of herbal essential oils or a-tocopheryl acetate on performance parameters and oxidation of body lipid in broilers. South Afr. J. Anim. Sci. 34: 52-61. http://dx.doi.org/10.4314/sajas.v34i1.4039

8. Brenes, A., Viveros, A., Goni, I., Centeno, C., Sayago-Ayerdy, S.G., Arija, I., Saura-Calixto, F., 2008. Effect of Grape Pomace Concentrate and Vitamin E on Digestibility of Polyphenols and Antioxidant Activity in Chickens. Poult. Sci. 87: 307-316. http://dx.doi.org/10.3382/ps.2007-00297

9. Cano, A., Medina, A., Bermejo, A., 2008. Bioactive compounds in different citrus varieties.

Discrimination among cultivars. J. Food Compost. Anal. 21: 377-381.

http://dx.doi.org/10.1016/j.jfca.2008.03.005

10. Chávez-Carbajal, A., Nirmalkar, K., Pérez-Lizaur, A., Hernández-Quiroz, F., Ramírez-Del-Alto, S., GarcíaMena, J., Hernández-Guerrero, C., 2019. Gut microbiota and predicted metabolic pathways in a sample of Mexican women affected by obesity and obesity plus metabolic syndrome. Int. J. Mol. Sci. 20: 438. http://dx.doi.org/10.3390/ijms20020438.

11. Cho, J., 2006. Antioxidant and neuroprotective effects of hesperidin and its aglycone hesperetin. Arch. Pharmacol. Res. 29: 699-706. http://dx.doi.org/10.1007/BF02968255.

12. Croft, K.D., 1998. The chemistry and biological effects of flavonoids and phenolic acids. Ann, N Y Acad. Sci. 854: 435-42. http://dx.doi.org/10.1111/j.1749-6632.1998.tb09922.x.

13. Cross, D.E., Mcdevitt, R.M., Hillman, K., Acamovic, T., 2007. The effect of herbs and their associated essential oils on performance, dietary digestibility and gut microflora in chickens from 7 to 28 days of age. Br. Poult. Sci. 48: 496-506. http://dx.doi.org/10.1080/00071660701463221.

14. Cushnie, T.P.T. and Lamb, A.J., 2011. Recent advances in understanding the antibacterialproperties of flavonoids, Int. J. Antimicrob. Agents. 38: 99-107. http://dx.doi.org/10.1016/j.ijantimicag.2011.02.014. 
15. Dueñas M., Muñoz-González I., Cueva, C., Jiménez - Girón, A., Sánchez - Patán, F., Santos-Buelga, C., Bartolomé, B., 2015. A survey of modulation of gut microbiota by dietary polyphenols. Bio. Med. Res. Int. 85092. http://dx.doi.org/10.1155/2015/850902.

16. Danneskiold-Samsøe, N.B., Dias de Freitas Queiroz Barros, H., Santos, R., Bicas, J.L., Cazarin, C.B.B., Madsen, L., Kristiansen, K., Pastore, G.M., Brix, S., Maróstica Júnior, M.R., 2019. Interplay between food and gut microbiota in health and disease. Food Res. Int. 115: 23-31. http://dx.doi.org/10.1016/j.foodres.2018.07.043

17. Etxeberria, U., Fernández- Quintela, A., Milagro, F.I., Aguirre, L., Martínez, J.A., Portill M.P., 2013. Impact of polyphenols and polyphenol-rich dietary sources on gut microbiota composition. J. Agr. Food. Chem. 61: 9517-9533. https://doi.org/10.1021/jf402506c

18. Escudero-Lopez, B., Calani, L., Fernandez-Pachon, M.-S., Ortega, A., Brighenti, F., Crozier, A., Del Rio, D., 2014. Absorption, metabolism, and excretion of fermented orange juice (poly)phenols in rats. Biofactors. 40: 327-335. http://dx.doi.org/10.1002/biof.1152

19. Estruel-Amades, S., M. Massot-Cladera, P., Garcia-Cerdà, F. J., Pérez-Cano, À., Franch, M., Castell M., Camps-Bossacoma, M., 2019. Protective effect of hesperidin on the oxidative stress induced by an exhausting exercise in intensively trained rats. Nutrients. 11: 783. http://dx.doi.org/10.3390/nu11040783.

20. Goliomytis, M., Kartsonas, N., Charismiadou, M.A., Symeon, G.K., Simitzis, P.E., Deligeorgis, S.G., 2015. The influence of naringin or hesperidin dietary supplementation on broiler meat quality and oxidative stability. PLoS One. 10: e0141652. https://doi.org/10.1371/journal.pone.0141652

21. Giannenas, I., Tontis, D., Tsalie, E., Chronis, E.F., Doukas, D., Kyriazakis, I., 2010. Influence of dietary mushroom agaricus bisporus on intestinal morphology and microflora composition in broiler chickens. Res. Vet. Sci. 89: 78-84. http://dx.doi.org/10.1016/j.rvsc.2010.02.003

22. Glorieux, C., Calderon, P.B., 2017. Catalase, a remarkable enzyme: Targeting the oldest antioxidant enzyme to find a new cancer treatment approach. Biol. Chem. 398: 1095-1108. http://dx.doi.org/10.1515/hsz-2017-0131

23. Goni, I., Brenes, A., Centeno, C., Viveros, A., Saura-Calixto, F., Rebole, A., Arija, I., Estevez, R., 2007. Effect of Dietary Grape Pomace and Vitamin E on Growth Performance, Nutrient Digestibility, and Susceptibility to Meat Lipid Oxidation in Chickens. Poult. Sci. 86: 508-516. https://doi.org/10.1093/ps/86.3.508

24. Griess, B., Tom, E., Domann, F., Teoh-Fitzgerald, M., 2017. Extracellular superoxide dismutase and its role in cancer. Free Radic. Biol. Med. 112: 464-479. http://dx.doi.org/10.1016/j.freeradbiomed.2017.08.013.

25. Guo, X., Li, K., Guo, A., Li, E., 2020. Intestinal absorption and distribution of naringin, hesperidin, and their metabolites in mice. J. Funct. Foods. 74: 104158, https://doi.org/10.1016/j.jff.2020.104158

26. Hanieh, H., Gerile, C., Narabara, K., Gu, Z., Abe, A., Kondo, Y., 2010. In vivo immunomodulatory effects of dietary purple sweet potato after immunization in chicken. Anim. Sci. J. 81: 116-121. http://dx.doi.org/10.1111/j.1740-0929.2009.00715.x 
27. Hassanpour, H., Zamani, M.A.K., Yazdani, A., Cheraghchi, B.M., 2010. Evaluation of intestinal morphology and nitric oxide metabolites in broiler chickens supplemented by green tea. Comp. Clin. Pathol. 19: 43-47. ISSN: 1618-5641

28. Hollman, P.C.H. and Katan, M.B., 1999. Dietary Flavonoids: Intake, Health Effects and Bioavailability. Food Chem. Toxicol. 37: 937-942. http://dx.doi.org/10.1016/s0278-6915

29. Hu, Z. and Guo, Y., 2007. Effects of dietary sodium butyrate supple-mentation on the intestinal morphological structure, absorptive function and gut flora in chickens. Anim. Feed Sci. Technol. 132: 240-249. http://dx.doi.org/10.1016/j.anifeedsci.2006.03.017

30. Jin, L.Z., Ho, Y.W., Abdullah, N., Jalaludin, S., 1996. Influence of dried Bacillus subtilis and lactobacilli cultures on intestinal microflora and performance in broilers. Asian-australas. J. Anim. Sci, 9:397404. https://doi.org/10.5713/ajas.1996.397

31. Joshi, R., Kulkarni, Y.A., Wairkar, S., 2018. Pharmacokinetic, pharmacodynamic and formulations aspects of Naringenin: An update. Life Sci. 215: 43-56. https://doi. org/10.1016/j.Ifs.2018.10.066.

32. Jung, U.J., Lee, M.K., Jeong, K.S., Chol, M.S., 2004. The hypoglycemic effects of hesperidin and naringin are partly mediated by hepaticglucose regulating enzymes in C57 BL/KsJ-db/db Mice. J. Nutr. 134: 2499-2503. http://dx.doi.org/10.1093/jn/134.10.2499

33. Kamboh, A.A. and Zhu, W.Y., 2014. Individual and combined effects of genistein and hesperidin on immunity and intestinal morphometry in lipopolysacharide-challenged broiler chickens. Poult. Sci. 93: 2175-2183. https://doi.org/10.3382/ps.2014-03971

34. Khedr, N.F., 2015. Protective effect of mirtazapine and hesperidin on cyclophosphamide-induced oxidative damage and infertility in rat ovaries. Exp. Biol. Med. 240: 1682-1689. http://dx.doi.org/10.1177/1535370215576304

35. Knight, J.A. 2000. Review: Free radicals, antioxidants, and the immune system. Ann. Clin. Lab. Sci. 30: $145-158$

36. Kumar, A., Lalitha, S., Mishra, J., 2014. Hesperidin potentiates the neuroprotective effects of diazepam and gabapentin against pentylenetetrazole-induced convulsions in mice: Possible behavioral, biochemical and mitochondrial alterations. Indian J. Pharmacol. 46: 309-315. http://dx.doi.org/10.4103/0253-7613.132180

37. Lee, S.J., Yun, Y.S., Lee, I.K., Ryoo, I.J., Yun, B.S., Yoo, I.D., 1999. An antioxidant lignan and other constituents from the root bark ofHibiscus syriacus. Planta Med. 65: 658-660. http://dx.doi.org/10.1055/s-2006-960841

38. Li, Z.L., Gao, M., Yang, B.C., Zhang, H.L., Wang, K.K., Liu, Z.L., Xiao, X., Yang, M.S., 2018, Naringin attenuates MLC phosphorylation and NF-kappaB activation to protect sepsis-induced intestinal injury via RhoA/ROCK pathway. Biomed. Pharmacother. 103: 50-58.

http://dx.doi.org/10.1016/j.biopha.2018.03.163

39. Lien, T.F., Yeh, H.S., Su, W.T. 2008. Effect of adding extracted hesperetin, naringenin and pectin on egg cholesterol, serum traits and antioxidant activity in laying hens. Arch. Anim. Nutr. 62: 3343. http://dx.doi.org/10.1080/17450390701780318 
40. Liu, Z., Ren, Z., Zhang, J., Chuang, C.C., Kandaswamy, E., Zhou, T., Zuo, L., 2018. Role of ROS and nutritional antioxidants in human diseases. Front. Physiol. 9: 477

41. Liu, Z., Ren, Z., Zhang, J., Chuang, C.C., Kandaswamy, E., Zhou, T., Zuo, L., 2018. Role of ROS and nutritional antioxidants in human diseases. Front. Physiol. 9:

477. http://dx.doi.org/10.3389/fphys.2018.00477

42. Martini N.D., Katerere D.R.P., Eloff J.N., 2004. Biological activity of five antibacterialflavonoids from Combretum erythrophyllum (Combretaceae), J. Ethnopharmacol. 93: 207-212. http://dx.doi.org/10.1016/j.jep.2004.02.030

43. NRC, 1994. Nutrient Requirements of Poultry. 9th Edn., National Academy Press, Washington, DC. USA.

44. Ohtsuki, K., Abe, A., Mitsuzumi, H., Kondo, M., Uemura, K., Iwasaki, Y., Kondo, Y., 2003. Glucosyl hesperidin improves serum cholesterol composition and inhibits hypertrophy in vasculature. J Nutr Sci Vitaminol (Tokyo). 49: 447-50. http://dx.doi.org/10.3177/jnsv.49.447

45. Parhiz, H., Roohbakhsh, A., Soltani, F., Rezaee, R., Iranshahi, M., 2015. Antioxidant and antiinflammatory properties of the citrus flavonoids hesperidin and hesperetin: an updated review of their molecular mechanisms and experimental models. Phytother Res. 29: 323-331 http://dx.doi.org/10.1002/ptr.5256

46. Pingitore, A., Pace, G., Lima, P., Mastorci, F., Quinones, A., lervasi, G., Vassalle, C., 2015. Exercise and oxidative stress: Potential effects of antioxidant dietary strategies in sports. Nutr. 31: 916-922. http://dx.doi.org/10.1016/j.nut.2015.02.005

47. Roohbakhsh, A., Parhiz, H., Soltani, F., Rezzee, R., Iranshahi, M., 2015. Molecular mechanisms behind the biological effects of hesperidin and hesperetin for the prevention of cancer and cardiovascular diseases. Life Sci. 124: 64-74

48. Roohbakhsh, A., Parhiz, H., Soltani, F., Rezzee, R., Iranshahi, M., 2015. Molecular mechanisms behind the biological effects of hesperidin and hesperetin for the prevention of cancer and cardiovascular diseases. Life Sci. 124: 64-74. http://dx.doi.org/10.1016/j.Ifs.2014.12.030

49. Ross, J.A. and Kasum, C.M., 2002. Dietary flavonoids: bioavailability, metabolic effects, and safety. Annu Rev Nutr. 22: 19-34. http://dx.doi.org/10.1146/annurev.nutr.22.111401.144957

50. Selvaraj, P., Pugalendi, K.V., 2012. Efficacy of hesperidin on plasma, heart and liver tissue lipids in rats subjected to isoproterenol-induced cardiotoxicity. Exp. Toxicol. Pathol. 64: 449-52. http://dx.doi.org/10.1016/j.etp.2010.10.012.

51. Simitzis, P.E., Symeon, G.K., Charismiadou, M.A., Ayoutanti, A.G., Deligeorgis, S.G., 2011. The effects of dietary hesperidin supplementation on broiler performance and chicken meat characteristics. Can. J. Anim. Sci. 911: 275-282. https://doi.org/10.4141/cjas10094

52. Ting, S., Yeh, H.S., Lien, T.F., 2011. Effects of supplemental levels of hesperetin and naringenin on egg quality, serum traits and antioxidant activity of laying hens. Anim. Feed Sci. Technol. 163: 59-66. http://dx.doi.org/10.1016/j.anifeedsci.2010.10.001 
53. Viveros, A., Chamorro, S., Pizarro, M., Arija, I., Centeno, C., Brenes, A., 2011. Effects of dietary polyphenol-rich grape products on intestinal microflora and gut morphology in broiler chicks. Poult. Sci., 90: 566-578. http://dx.doi.org/10.3382/ps.2010-00889

54. Wallace, J., Oleszek, W., Franz, C., Hahn, I., Baser, K.H., Mathe, A., Teichmann, K., 2010. Dietary plant bioactives for poultry health and productivity. Br. Poult. Sci. 51: 461-487. http://dx.doi.org/10.1080/00071668.2010.506908

55. Zhang, Y.S. Li, Y. Wang, Y., Sun, S.Y., Qu, X.J., 2015. Naringin, a natural dietary compound, prevents intestinal tumorigenesis in apc (min/+) mouse model. J. Cancer Res. Clin. Oncol. 178: 1-13. http://dx.doi.org/10.1007/s00432-015-2097-9

\section{Tables}

Table 1. The effect of hesperidin added to quail diets on blood serum biochemistry. 


\begin{tabular}{|lllll|}
\hline & C & HES1 & HES2 & \\
\hline & Mean \pm Std.error & Mean \pm Std.error & Mean \pm Std.error & $p$ \\
\hline Tchol, mg/dl & $239.82 \pm 9.09$ & $262.38 \pm 7.22$ & $259.23 \pm 5.32$ & 0.12 \\
\hline TG, mg/dl & $265.35 \pm 24.77$ & $248.40 \pm 25.59$ & $247.43 \pm 26.77$ & 0.86 \\
\hline ALT, u/l & $5.50 \pm 0.65 a b$ & $4.25 \pm 0.48 \mathrm{~b}$ & $6.60 \pm 0.25 \mathrm{a}$ & $0.01^{\star}$ \\
\hline AST, u/l & $237.50 \pm 6.89^{\mathrm{a}}$ & $243.00 \pm 5.51^{\mathrm{a}}$ & $194.60 \pm 9.66^{\mathrm{b}}$ & $0.00^{\star}$ \\
\hline GGT, u/l & $2.00 \pm 0.58$ & $2.40 \pm 0.40$ & $3.50 \pm 0.50$ & 0.14 \\
\hline ALP, u/l & $265.73 \pm 22.42$ & $279.37 \pm 26.89$ & $261.70 \pm 26.62$ & 0.89 \\
\hline CK, u/l & $2.422 \pm 197.57$ & $2.614 \pm 211.07$ & $2.650 \pm 242.93$ & 0.78 \\
\hline LDH, u/l & $711.93 \pm 36.69^{\mathrm{ab}}$ & $678.36 \pm 27.69^{\mathrm{b}}$ & $767.81 \pm 13.88^{\mathrm{a}}$ & $0.03^{\star}$ \\
\hline Amylase, u/l & $243.50 \pm 15.50^{\mathrm{b}}$ & $302.75 \pm 12.15^{\mathrm{ab}}$ & $355.50 \pm 18.68^{\mathrm{a}}$ & $0.01^{*}$ \\
\hline BUN, mg/dl & $4.00 \pm 0.00$ & $4.67 \pm 0.33$ & $4.71 \pm 0.36$ & 0.26 \\
\hline Albumin, g/dl & $1.83 \pm 0.11$ & $1.55 \pm 0.17$ & $1.83 \pm 0.10$ & 0.24 \\
\hline TP, g/dl & $6.26 \pm 0.71$ & $3.97 \pm 0.21$ & $4.74 \pm 0.55$ & 0.08 \\
\hline Urea, mg/dl & $8.54 \pm 0.38$ & $8.65 \pm 0.40$ & $9.98 \pm 0.46$ & 0.06 \\
\hline Creatin, mg/dl & $0.18 \pm 0.02$ & $0.16 \pm 0.01$ & $0.19 \pm 0.04$ & 0.82 \\
\hline Glukoz, mg/dl & $56.58 \pm 9.66$ & $61.60 \pm 5.40$ & $59.20 \pm 2.20$ & 0.93 \\
\hline Ca, mg/dl & $10.52 \pm 0.20$ & $8.87 \pm 0.76$ & $9.99 \pm 0.10$ & 0.16 \\
\hline Mg, mg/dl & $7.58 \pm 0.64$ & $6.18 \pm 0.50$ & $7.56 \pm 0.24$ & 0.09 \\
\hline P, mg/dl & $16.68 \pm 9.45$ & $16.55 \pm 0.76$ & $17.70 \pm 0.50$ & 0.32 \\
\hline
\end{tabular}

Tchol: Total cholestrol, BUN: Blood Urea Nitrogen, ALT: Alanine amino Transferase, AST: Aspartate amino Transferase, GGT: Gamma Glutamyl Transferase, ALP: Alkaline Phosphatase, TP: Total Protein, TG: Triglyceride, CK: Creatin Kinase, LDH: Lactate Dehydrogenase, P: Phosphorus.

*There is a statistically significant difference between the experimental groups $(p<0.05)$

Table 2. The effect of hesperidin added to the diet on antioxidant parameters in thigh, liver and blood serum. 


\begin{tabular}{|c|c|c|c|c|c|}
\hline & & C & HES1 & HES2 & \\
\hline & & Mean \pm Std.error & Mean \pm Std.error & Mean \pm Std.error & $\mathrm{p}$ \\
\hline \multirow[t]{3}{*}{$\mathrm{GSH}, \mu \mathrm{mol} / \mathrm{L}$} & Thigh & $10.79 \pm 0.49$ & $12.61 \pm 0.16$ & $10.04 \pm 0.75$ & $0.06 *$ \\
\hline & Liver & $6.33 \pm 1.01^{c}$ & $12.77 \pm 0.65^{b}$ & $19.62 \pm 0.65^{a}$ & 0.00 * \\
\hline & Serum & $51.68 \pm 1.34^{b}$ & $75.16 \pm 1.24^{a}$ & $70.88 \pm 0.42^{a}$ & $0.01^{*}$ \\
\hline \multirow[t]{3}{*}{$\mathrm{SOD}, \mathrm{U} / \mathrm{ml}$} & Thigh & $1.03 \pm 0.04^{\mathrm{a}}$ & $0.81 \pm 0.04^{b}$ & $0.85 \pm 0.07^{b}$ & $0.02^{\star}$ \\
\hline & Liver & $1.09 \pm 0.02$ & $1.11 \pm 0.03$ & $1.16 \pm 0.01$ & 0.14 \\
\hline & Serum & $0.37 \pm 0.12$ & $0.32 \pm 0.13$ & $0.42 \pm 0.11$ & 0.84 \\
\hline \multirow[t]{3}{*}{ CAT, U/ml } & Thigh & $211.62 \pm 0.72^{\mathrm{a}}$ & $101.55 \pm 1.16^{b}$ & $61.56 \pm 0.91^{c}$ & 0.00 * \\
\hline & Liver & $76.13 \pm 1.31^{b}$ & $88.40 \pm 4.18^{\mathrm{ab}}$ & $96.69 \pm 3.43^{a}$ & 0.01 * \\
\hline & Serum & $54.30 \pm 1.06^{\mathrm{ab}}$ & $51.33 \pm 1.25^{b}$ & $61.65 \pm 1.03^{a}$ & $0.02^{\star}$ \\
\hline \multirow[t]{3}{*}{ TBARS, $\mu \mathrm{mol} / \mathrm{L}$} & Thigh & $758.53 \pm 42.62^{\mathrm{a}}$ & $642.30 \pm 43.17^{\mathrm{ab}}$ & $379.71 \pm 40.09^{b}$ & $0.02 *$ \\
\hline & Liver & $1.091 .16 \pm 40.52^{\mathrm{a}}$ & $318.98 \pm 39.98^{b}$ & $308.31 \pm 31.66^{c}$ & 0.00 * \\
\hline & Serum & $777.69 \pm 36.18^{a}$ & $438.24 \pm 35.80^{b}$ & $298.32 \pm 38.67^{b}$ & 0.01 * \\
\hline \multirow[t]{3}{*}{ LPO, $\mu \mathrm{mol} / \mathrm{L}$} & Thigh & $278.79 \pm 1.46^{a}$ & $285.13 \pm 1.15^{a}$ & $267.28 \pm 2.34^{b}$ & $0.03^{*}$ \\
\hline & Liver & $257.09 \pm 1.39^{a}$ & $241.16 \pm 0.78^{b}$ & $249.30 \pm 1.29^{a}$ & 0.01 * \\
\hline & Serum & $241.56 \pm 1.56^{b}$ & $279.88 \pm 1.42^{\mathrm{a}}$ & $284.71 \pm 1.52^{\mathrm{a}}$ & 0.00 * \\
\hline
\end{tabular}

GSH: Reduced glutathione, SOD: Superoxide dismutase, CAT: Catalase, TBARS: Thiobarbutiric acid reactive substances, LPO: Lipid peroxide.

*There is a statistically significant difference between the experimental groups $(p<0.05)$

Table 3. The effect of hesperidin added to the diet on villus and crypt depth in the ileum, caecum and colon. 


\begin{tabular}{|c|c|c|c|c|c|}
\hline & & $\mathrm{C}$ & HES1 & HES2 & \\
\hline & & Mean \pm Std.error & Mean \pm Std.error & Mean \pm Std.error & $p$ \\
\hline \multirow[t]{3}{*}{ Ileum } & VH & $222.42 \pm 13.53$ & $234.53 \pm 21.69$ & $264.24 \pm 22.43$ & 0.33 \\
\hline & VW & $67.21 \pm 1.97$ & $64.70 \pm 5.47$ & $67.10 \pm 2.54$ & 0.86 \\
\hline & $C D$ & $30.50 \pm 1.24$ & $31.71 \pm 1.82$ & $35.02 \pm 3.55$ & 0.41 \\
\hline \multirow[t]{3}{*}{ Cecum } & $\mathrm{VH}$ & $71.40 \pm 3.79^{b}$ & $85.56 \pm 4.24^{\mathrm{a}}$ & $79.86 \pm 1.28^{\mathrm{ab}}$ & $0.03 *$ \\
\hline & VW & $41.33 \pm 2.47$ & $42.76 \pm 1.28$ & $47.81 \pm 1.55$ & 0.06 \\
\hline & $C D$ & $44.45 \pm 3.45$ & $38.15 \pm 1.78$ & $41.80 \pm 1.58$ & 0.22 \\
\hline \multirow[t]{3}{*}{ Colon } & $\mathrm{VH}$ & $226.38 \pm 18.21^{b}$ & $298.58 \pm 22.10^{\mathrm{ab}}$ & $312.50 \pm 28.75^{a}$ & $0.04 *$ \\
\hline & VW & $60.88 \pm 2.01^{b}$ & $73.70 \pm 3.84^{a}$ & $62.54 \pm 3.13^{\mathrm{ab}}$ & $0.02^{\star}$ \\
\hline & $C D$ & $53.47 \pm 4.65^{a}$ & $40.24 \pm 2.89^{b}$ & $42.62 \pm 2.39^{a b}$ & $0.04 *$ \\
\hline
\end{tabular}

VY: Villus Height, VG: Villus Width, KD: Crypt Depth.

*There is a statistically significant difference between the experimental groups $(p<0.05)$

Table 4. Bacteria count (gram/Log10) in stool samples taken from quails fed diets supplemented with hesperidin.

\begin{tabular}{llllc} 
& $\mathrm{C}$ & HES1 & HES2 & \\
& Mean \pm Std.error & Mean \pm Std.error & Mean \pm Std.error & $\mathrm{p}$ \\
\hline Escherichia coli & $6.51 \pm 0.30$ & $6.55 \pm 0.27$ & $6.11 \pm 0.43$ & 0.61 \\
\hline Enterococcous spp. & $6.37 \pm 0.34$ & $6.05 \pm 0.28$ & $6.77 \pm 0.25$ & 0.27 \\
\hline Coliform spp. & $6.27 \pm 0.36$ & $6.09 \pm 0.25$ & $5.44 \pm 0.18$ & 0.20 \\
\hline Enterobactericeae & $6.43 \pm 0.24$ & $5.65 \pm 0.26$ & $6.65 \pm 0.24$ & 0.88 \\
\hline Clostridium spp. & $6.55 \pm 0.07^{\mathrm{a}}$ & $5.93 \pm 0.27^{\mathrm{a}}$ & $5.26 \pm 0.11^{\mathrm{b}}$ & $0.01^{\star}$
\end{tabular}

*There is a statistically significant difference between the experimental groups $(p<0.05)$

\section{Figures}



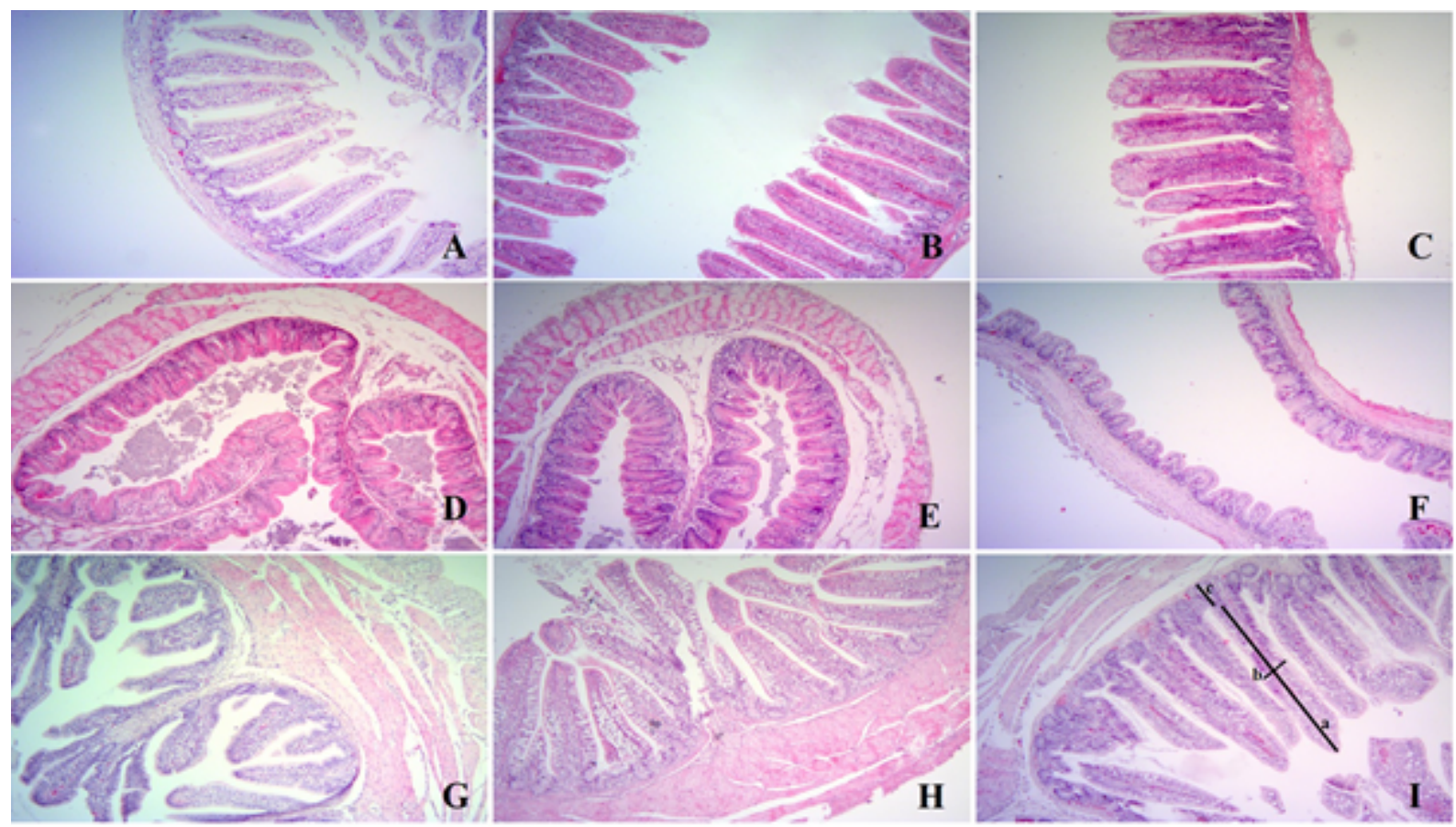

Figure 1

Control group: ileum (A), cecum (D), colon (G), HES1 group: ileum (B), cecum (E), colon (H), HES2 group: ileum (C), cecum (F), colon (I) tissue. a: villus hight, b: villus width, c: crypt depth. Hematoxylin-Eosin staining $\mathrm{X} 10$. 